\title{
SYNTHESIS AND CHARACTERIZATION OF SOME METAL COMPLEXES WITH IETS AS LIGAND DERIVED FROM 2-ACETLYLINDAN-1,3-DIONE
}

\author{
Devesh Kumar, Dr Vipin Kumar Singh, Dr S. S. Khiwar, Dr neeraj Saxena \\ Agra College, Dr B.R. Ambedkar University, Agra(U.P.), India \\ *Corresponding Author's Email: devesh2015@gmail.com
}

\begin{abstract}
:
The present investigation are based on the synthesis and characterization of metal complexes with Schiff's bases (anils) $\alpha-(1$, 3- dioxo- indan-2-yl) - ethylidene- thiosemicarbazone(IETS) derived from 2-substituted acetyl 1, 3 - dione by condensing it with primary aryl amine (aniline) in absolute alcohol. 2-acetyl indan-1, 3-dione was prepared by claisen-condensation. The Co (II), Ni(II), Cu (II), Zn (II), Cd (II), Fe (III), V (III) and Cr (III) complexes of the Schiff's bases have been prepared in the reactions and investigated their structures by physicochemical methods. The formulation and structure of the ligands have been screened by their chemical analysis, IR, PMR and mass-spectral studies. The PMR spectrum of the metal complexes in quite similar to the PMR spectrum of the anil (IETS) with slight change in the position of PMR signals. The metal compl exes are thermally stable at higher temperature $\left(-300^{\circ}\right)$. These characteristics suggest polymeric nature of the metal complexes. The observed molar conductance values of the complexes with IETS have been found in the range 170 to $250 \mathrm{mhos} \mathrm{cm}^{2} \mathrm{~g} \mathrm{~mol}^{-1}$. The mass-spectra of this IETS showed the molecular ion peak as a base peak at $\mathrm{m} / \mathrm{z} 261$. The structure of ligand has been confirmed by their mass-spectral studies.
\end{abstract}

Keywords: Metal Complexes, Schiff's bases, 2-Acetlylindan-1,3-Dione

\section{INTRODUCTION}

Schiff's bases or anills have been found to be immense importance and versatile complexing agents. large number of transition metal complexes have been synthesized and charatarised with schiff's bases which have been proved of wide utility, semicarbazone and thiosemicarbazone have joined special attentation due to their activity against protozoa, influenza, small pox, malaria, tuber-culosis ${ }^{1-2}$, and antitumor activity of their meatal complexes. ${ }^{3-4}$ Metal complexes of thiosemicarbazone have emerged as new class of chemotherapeutic agent which exhibit inhibitory activity against most cancers through inhibition of a crucial enzyme, obligatory for DNA biosynthesis and cell division. Due to wide range of medicinal use of metal complexes of semicarbazone/thiosemicarbazone. Co(II), $\mathrm{Ni}(\mathrm{II}), \mathrm{Cu}(\mathrm{II})$ etc. metal complexes with these ligands have been prepared and reported..$^{5-8}$

Because of their versatile biological activity and prospective use as drugs. ${ }^{9}$ Owing to the interest they generate through a variety of biological prosperties ranging from anticancer, ${ }^{10}$ antitumor, ${ }^{11}$ antifungal, ${ }^{12}$ antibacterial ${ }^{13}$ antimalarial, ${ }^{14}$ antitilarial, ${ }^{15}$ antiviral, ${ }^{16}$ anti-HIV ${ }^{17}$ activities, thiosemicabazones and their metal complexes have been extensively studied.

The ability of thiosemicarbazone molecule to chelate with traces of metals in the biological system is believed to be a reason for their activity. The lipophilicity of thio semi carbazone controls the rate of entry of trace metals into the cell. This modified by cordination and some side effects may be decreased ${ }^{87-88}$. It has been proved that thiosemcarbazone block DNA synthesis in mammalian cells big by inhibiting the enzymes, ribonucleosidediphosphate reductase, presumably either via chelation with an iron ion required by the enzymes or because a performed metal chellate of the inhibitor interacts with the target enzyme ${ }^{18}$. The reports also point out the capacity of thiosemicarbazon to saver the DNA stands ${ }^{19}$.

The antitumor activities of $\mathrm{Mn}$ (II), $\mathrm{Ni}$ (II), and $\mathrm{Cu}$ (II) chelates of anthracene -9 -carboxyldehyde thiosemicarbazone 20 and the cytotoxic activity of phenylglyoxal bis (thiosemicarbazone) against Ehrlichascitess carcinoma cells have been reported.

Platinum complexes of 2-acetylpyriden thiosemicarbazone have been synthesized in which intermolecular hydrogen bonds, $\pi-\pi$ and weak $\mathrm{pt}-\mathrm{pt}$ and pt $-\pi$ contacts lead to aggregation and to a twodimensional supra molecular assembly. The complexes were found to have a completely lethal effect on Gram +ve bacteria.

Thiosemicarbazones are thio urea derivatives obtained by condensation of thiosemicarbazide or N(4)substituted thiosemicarbazide with a suitable aldehyde or ketone. The thiosemi- carbazones are represented by the general formula and when $\mathrm{N}(4)$ is substituted they can represented by the general formula.

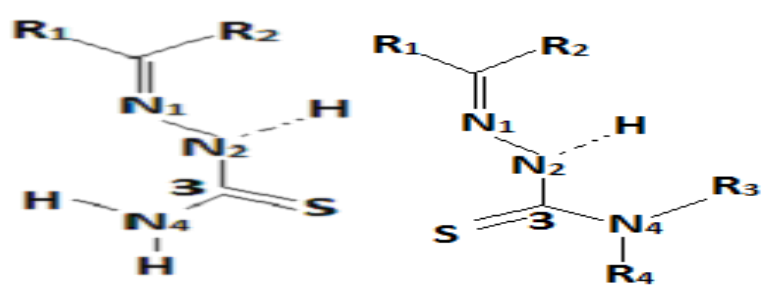


$11 \underline{\mathrm{H}}-$ indeno[1,2- $\underline{\mathrm{b}}]$ quinoline and $6 \underline{\mathrm{H}}-$-indeno[2,1- $\underline{\mathrm{b}}]$ quinoline have been synthesized and screened for their carcenogenic and antitumor activities. ${ }^{21,22}$<smiles></smiles>

Houliham and his coworkers ${ }^{23}$ synthesizes 3substituted-2,4-dihydroindeno(1,2- C)__pyrazoles and screened them for their antihypertensieve, contraceptive and abortifacient activity. At a level of $1-100 \mathrm{mg} / \mathrm{day}$, pyrazoles $^{24}$ actid as antifertility agent in rats and 2-200 $\mathrm{mg} / \mathrm{Kg}$ behaved as antihypertensive agents.

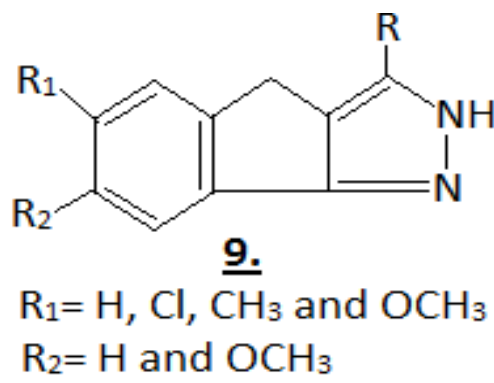

\section{$\mathrm{R}=2{ }^{-}, 3^{-}, 4^{-}$pyridyl, 2- furyl, 2- thienyl, Phenyl and substituted phenyl.}

From the detailed survey of the literature on condensed heterocyclic ring systems, it is evedent that indenoquinolenes and indenopyrazoles show various pharmacological and biological properties. Some 10substituted indenoquinolines are potent analgesics and anti-inflammatory agents. Among pyrazoles fused to carbocyclic and heterocyclic ring systems, indenopyrazoles occur a uniques position because of their wide spectrum of physiological properties. With this fact a series of substituted indenopyrazoles has been reported.

Indenoquinolines and indenopyrazoles consist of indane1, 3-dione moiety which may be responsible for their biological activity. This suggests that indanedione derivatives may possitively exhibit this property also. The Schiff's bases have been reported to be good complexing agents.

This seems to be worthwhile to synthesize 2-substituted 1,3-indanedione Ketones and their Schiff's bases (anils) by condensation them with aniline and various isomeric toleredines which could be used as complexing agents to prepare and characterize their metal derivatives. With this fact in thoughts the present research work has been carried out.

The present investigation aims at evolving $\mathrm{L}_{2}$, $\left[\mathrm{C}_{12} \mathrm{H}_{11} \mathrm{~N}_{2} \mathrm{O}_{25}\right]$, IETS, (1,3 - oxo - indane - 2yl) ethylidene thio semicarbazide. as ligands by utilizing easily available 2- acyl indane 1,3-dione and thiosemicarbazone etc. as starting materials, and formation of their metal derivatives. The following ligand has been synthesized, characterized and used in the preparation of their metal derivatives.

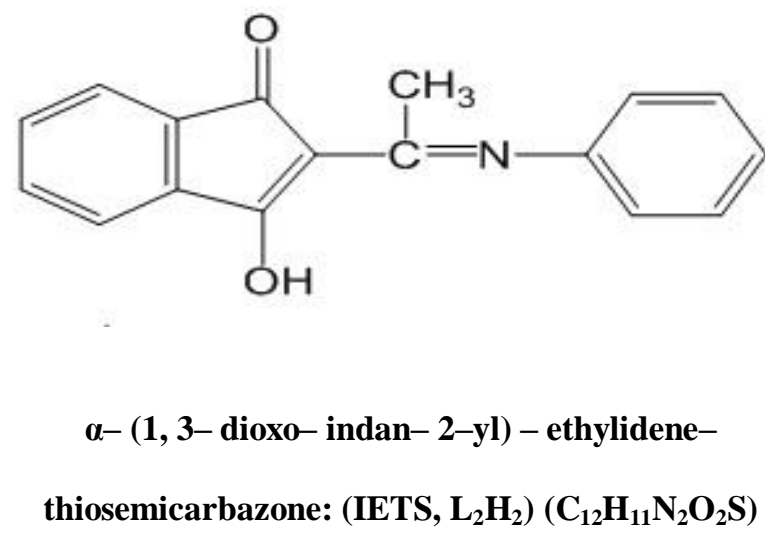

In the present work, the reactions of following metal derivatives of the IETS ligand have been isolated and characterized. i.e. Cobalt (II) chloride, Nickel (II) chloride, Copper (II) chloride, Zinc (II) chloride, Cadmium (II) chloride, Iron (III) chloride, Vanadium (III) chloride, Chromium (III) chloride

\section{MATERIAL AND METHODS}

\section{Material:}

All the chemicals used in this investigation were of good quality and analytical grade and were purchased from standard chemical agencies. Methanol and ethanol were first dried by refluxing over quicklime for four to six hours and then distilled over sodium wire. ${ }^{25,26}$ Acetaldehyde, Benzaldehyde and Acetone were dried over aluminium isoproxide and then distilled fractionally before use. ${ }^{27}$ Benzene and Thiosemicarbazine were purified and dried before use. Anhydrous metal salts (mostly chlorides) of $\mathrm{Co}(\mathrm{II}), \mathrm{Ni}(\mathrm{II}), \mathrm{Cu}(\mathrm{II}) \mathrm{Zn}$ (II), V(III), Cr(III) and Fe(III)(all Fluka, A.G. and B.D.H.) were used as such after confirming their purity by chemical analysis.

\section{Analytical methods:}

The composition of ligands and their metal derivatives was determined by elemental analysis such as quantitative analysis of carbon, hydrogen, nitrogen, halogen and metal ions by known standard methods. These studies were carried out in case of few selected ligands and their metal derivatives ${ }^{28}$.

Metal ions were estimated by known standard methods. The complexes were dissolved by decomposing first with concentrated nitric acid and then in hydrochloric acid. The solution was then heated to dryness or neutralized by suitable ways depending upon the method of analysis Iron $^{29}$, Cobalt ${ }^{30}$, Nickel ${ }^{31}$, Copper ${ }^{32}$, Zinc etc. were estimated by known standard methods. 


\section{Physical Measurements:}

\section{Molar Conductance:}

The variation is molar conductance of the metal complexes could be confirmed by molar conductance measurements of the complexes.

The reciprocal of the resistance is termed the conductance measured is reciprocal ohms or

$\Omega^{-1}$. The resistance of a sample of homogeneous solution, length(l), and cross section area (a), is given by:-

$$
\mathrm{R}=\rho .1 / \mathrm{a}
$$

$$
\mathrm{p}=\frac{\mathrm{R} \cdot \mathrm{a}}{1}
$$

$\mathrm{P}$ is a characterstic property of the material termed the resistivity. It is given by

When "l" and "a" are measured in meters and square meter than " $p$ " is measured in $\Omega$ meters. The reciprocal of resistivity is the conductivity $(\mathrm{K})$. The conductivity of 1 mole of the material is called molar conductance. $\mathrm{a} / \mathrm{l}$ is characterstic of conductivity cell, called cell constant.

The molar conductance of some selected metal derivatives has been determined by using sensitive conductivity bridge. First, the cell constant is determined. The cell $(x=a / 1)$ must be evaluated by caliberation with a solution of accurately known conductivity e.g. a standard Potassium choloride solution.

\section{Megnatic suspectibility measurements.}

The magnetic susceptibility of the synthesized metal complexes was determined by using "Gouy's" balance. The weights were measured by means of electrical balance. By changing the magnetic field change in weight of the compounds were recorded to determine their magnetic susceptibility values. The formula used is given as formula:-

$$
\psi_{\mathrm{m}}=\frac{2 \mathrm{mgL}}{\mathrm{m}^{\prime} \mathrm{H}^{2}} \text { C.G.S. Units. }
$$

Where:-

$\mathrm{m}=$ Change in mass of sample in magnetic field $(\mathrm{H})$,

$\mathrm{g}=$ acceleration due to gravity at that place.

$\mathrm{L}=$ Length of compound in the tube.

$\mathrm{m}^{1}=$ mass of compound field in the tube

The molecule suscotibility is given by equation:

$\psi_{\mathrm{M}}=\psi_{\mathrm{m}} \mathrm{X}$ molecular weight of the compound

or $\quad \psi_{\mathrm{M}}=\psi_{\mathrm{m}} \times \mathrm{M}$

The magnetic susceptibility after diamagnetic correction is given by relation

$$
\mu_{\text {eff }}=2.84 \sqrt{\psi_{x^{\prime}} T} \quad \text { B.M. }
$$

Where, $\mathrm{T}$ is absolute temperature copper sulphate was used as calibrant in all these determinations.

\section{Infra-Red measurement:}

Infra-red spectra of the ligands and their metal derivatives were recorded on Perkin - Elemer, 842infrared spectrometer using $\mathrm{KBr}$ Pallets in the region of $400-4000 \mathrm{~cm}^{-1}$.

\section{N.M.R. Studies:}

The PMR spectra of ligands and their metal complexes have been recorded by sending samples to research laboratory at K.U Kurushetra(Haryana) and CDRI lucknow. The NMR - studies helped in determining the structure and stereochemistry of the ligands and their metal derivatives.

\section{Mass - Spectral studies:}

The mass- spectrum of ligand and some metal derivatives were recorded on MS- 12, massspectrometer operating at $70 \mathrm{ev}$. The data given in parentheses represent relative intensities of peaks corresponding to the base peak taken as 100 .

\section{Synthesis of ligands:}

In present investigation $\alpha-(1,3-$ dioxo- indan- 2-yl) ethylidene- thiosemicarbazone: (IETS) ligand has been used to form its metal derivatives.

The general approach towards synthesis of IETS consists of an initial condensation of 2- substituted indane 1, 3dione, wih thiosemicarbazides etc. 
1. Synthesis of 2 - Acetyl indane - 1, 3- dione ${ }^{25}:-$

It was prepared by claisen - condensation of diethylphthalate and acetone in presence of sodium methoxide. The reaction proceeded through the following steps:

(b)
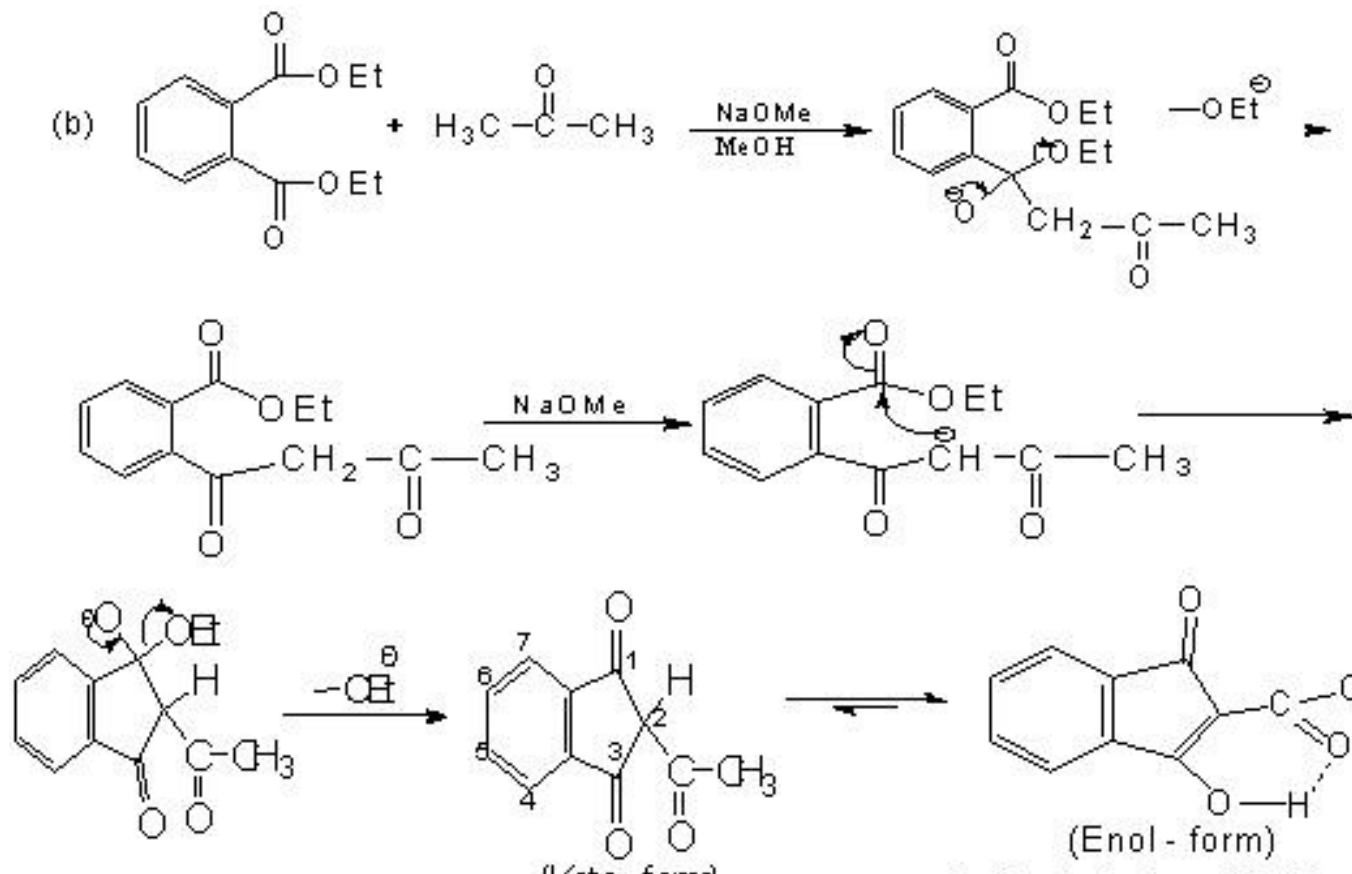

(Keto-form)

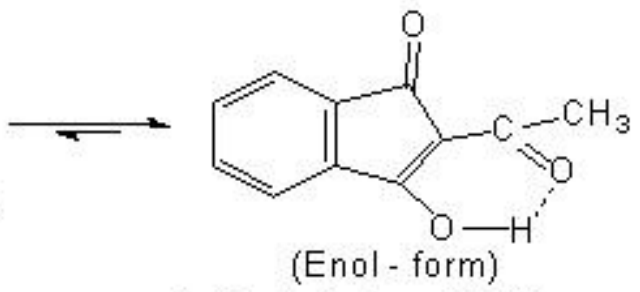

2- Acetyl indan-1,3-dione

The product was characterized by $1 \mathrm{R}$ and PMR spetral studies observed data are given below:

$$
\underline{\text { IR (Nujaol) } \mathrm{cm}^{-1}}
$$

$1710(\mathrm{~S},>\mathrm{C}=\mathrm{O})$, stretch in a five membered ring)

$1670-1620(\mathrm{~S}$, Chelated $>\mathrm{C}=\mathrm{O}$ stretch$)$

$1595(\mathrm{~s}), 1570(\mathrm{~s}), 1450(\mathrm{~s}), 1350(\mathrm{~m}), 1320(\mathrm{~s}), 1230(\mathrm{w}), 980(\mathrm{~m}), 860(\mathrm{~s}), 800(\mathrm{~m})$ and $730(\mathrm{~s})$.

\section{$\underline{\operatorname{PMR}\left(\mathrm{COCl}_{3}\right), \delta}$}

$2.50\left(\underline{\mathrm{S}}, 3 \mathrm{H},-\mathrm{COCH}_{3}\right), 7.40-7.80\left(\underline{\mathrm{m}}, 4 \mathrm{H}, \mathrm{C}_{4}-\mathrm{H}, \mathrm{C}_{5}-\mathrm{H}, \mathrm{C}_{6}-\mathrm{H} \& \mathrm{C}_{7}-\mathrm{H}\right)$ and $12.40\left(\mathrm{C}_{8}-\mathrm{OH}\right)$ enolic.

\section{Synthesis of $\alpha-(1,3-$ dioxo -indane - 2-yl) ethylidene thiosemi Carbazone (IETS):}

When 2-acetyl -3 indan-1,3-dione was refluxed with thiosemicarbazine in absolute ethanol then $\alpha$ - (1,3-dioxo-indane2yl) ethyliden thiosemicarbazone was obtained as yellowish-orange solid product in the reaction.

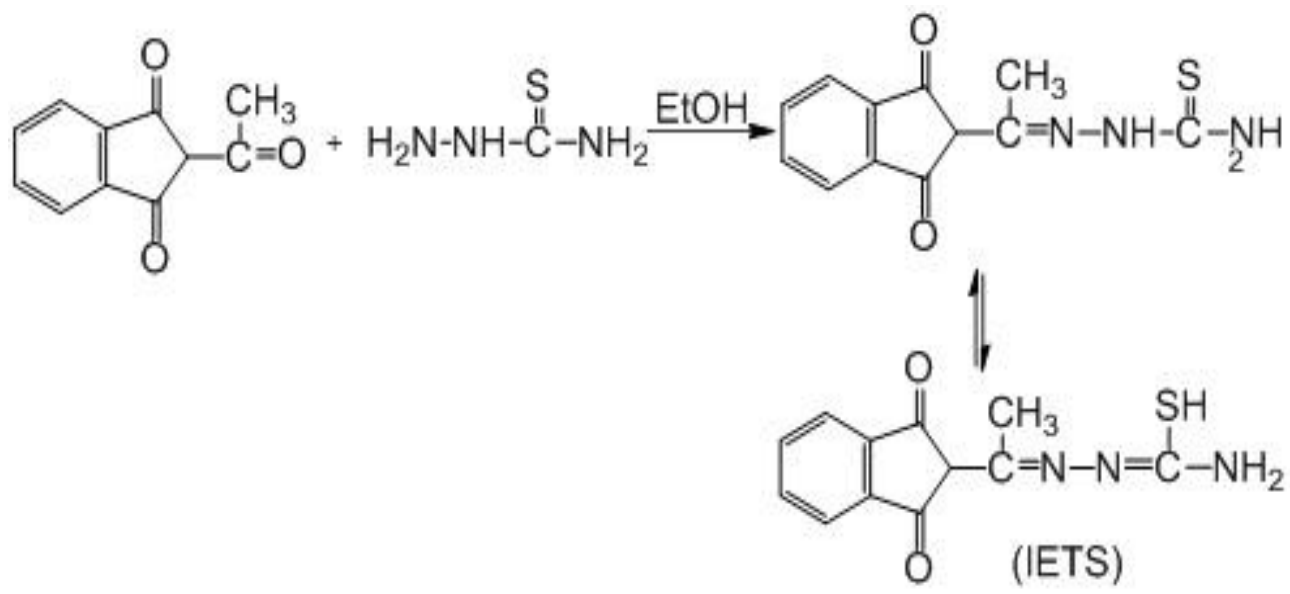

The structure of this anil (IETS) has been studied by its IR, PMR and mass spectral data given in table 1. 


\section{Preparation of metal derivatives:}

The present investigation is based upon the reactions between metal ions and ligand. The metal complexes of metal ions $\mathrm{Co}(\mathrm{II}), \mathrm{Ni}(\mathrm{II}), \mathrm{Cu}(\mathrm{II}), \mathrm{Zn}(\mathrm{II}), \mathrm{Cd}(\mathrm{II}), \mathrm{V}(\mathrm{II})$, $\mathrm{Cr}(\mathrm{II})$, and $\mathrm{Fe}$ (III) with ligand, indeno-ethylidene thiosemicarbazone (IETS) has been prepared in different molar ratios of metal to ligand. The general reactions may be represented as follows:

1. Reactions of ligands with bivalent metal ions; M(II) in MeOH solvent: -

(i) 1:1 molar ratio Reactions: -

$\mathrm{MX}_{2}+\mathrm{L}_{2} \mathrm{H}_{2} \longrightarrow \mathrm{ML}_{2} \mathrm{X} \cdot \mathrm{xMeOH}+\mathrm{HX}$

(ii) 1:2 molar ratio Reactions:-

$\mathrm{MX}_{2}+2 \mathrm{~L}_{2} \mathrm{H}_{2} \longrightarrow \mathrm{M}\left(\mathrm{L}_{2} \mathrm{H}\right)_{2} \cdot \mathrm{yMeOH}+2 \mathrm{HX}$

[x= Cl, M= Co(II), Ni(II), Cu(II), Zn(II), Cd(II)], [x=3, and $\mathrm{y}=2$, for $\mathrm{Co}(\mathrm{II}), \mathrm{Ni}(\mathrm{II})$ complexes].

2. Reactions of ligands with trivalent metal ions in MeOH solvent: -

(i) 1:1 molar ratio reactions: -

$\mathrm{MX}_{3}+\mathrm{L}_{2} \mathrm{H}_{2} \longrightarrow \mathrm{MLX}_{2} \cdot \mathrm{xMeOH}+2 \mathrm{HX}$

(ii) $1: 2$ molar ratio reactions: -

$\mathrm{MX}_{3}+2 \mathrm{~L}_{2} \mathrm{H}_{2} \longrightarrow \mathrm{M}\left(\mathrm{L}_{2} \mathrm{H}\right)_{2} \mathrm{X} \cdot \mathrm{yMeOH}+2 \mathrm{HX}$

(iii) 1:3 molar ratio Reactions: -

$\mathrm{MX}_{3}+3 \mathrm{~L}_{2} \mathrm{H}_{2} \longrightarrow \mathrm{M}\left(\mathrm{L}_{2} \mathrm{H}\right)_{3}+3 \mathrm{HX}$

$[\mathrm{x}=\mathrm{Cl}, \mathrm{M}=\mathrm{V}(\mathrm{III}), \mathrm{Cr}(\mathrm{III})$ and $\mathrm{Fe}(\mathrm{III})],[\mathrm{x}=2$, and $\mathrm{y}=1]$.

\section{RESULTS AND DISCUSSIONS}

IETS ligand has been synthesized, characterized and used in the preparation of their metal derivatives.
In the present work, the reactions of following metal derivatives of the IETS ligand have been isolated and characterized. i.e. Cobalt (II) chloride, Nickel (II) chloride, Copper (II) chloride, Zinc (II) chloride, Cadmium (II) chloride, Iron (III) chloride, Vanadium (III) chloride, Chromium (III) chloride

\section{Ligand(IETS):}

The starting material 2-acetyl indan-1, 3-dione ${ }^{14}$ was prepared by claisen-condensation of diethylphalate and acetone in presence of sodium metoxide

When 2-acetyl -3 indan-1,3-dione was refluxed with thiosemicarbazine in absolute ethanol; $\alpha$ - (1,3-dioxoindane-2yl) ethyliden thiosemicarbazone was obtained as yellowish-orange solid product in the reaction.

\section{Structure of the IETS}

The structure of the IETS has been studied by its IR, PMR and mass spectral data given in table 1.

\section{IR spectral studies}

The IR spectra of the ligand shows an absorption band at $3620^{\mathrm{cm}-1}$ which could be assigned to stretching frequency, $v(\mathrm{O}-\mathrm{H})$ phenolic and $v(\mathrm{~S}-\mathrm{H})$ stretching mode of vibrations. The observation of condense IR band at $3050^{\mathrm{cm}-1}$ may be due to $\mathrm{v}(\mathrm{C}-\mathrm{H})$ (aryl) stretching mode of vibrations and a band at $2995^{\mathrm{cm}-1}$ may be attributed to $v(\mathrm{C}-\mathrm{H})$ frequency in $\left(-\mathrm{CH}_{3}\right)$ group. A sharp intense band at $1700^{\mathrm{cm}-1}$ may be assigned to $v(\mathrm{C}=\mathrm{O})$ frequency in five membered ring. IR bands at $1640^{\mathrm{cm}-1}$ and $1460^{\mathrm{cm}-1}$ may be due to $v(\mathrm{C}=\mathrm{N})$ stretching vibrations. The IR band is thereyol $610-1450^{\mathrm{cm}-1}$ may be due to $\mathrm{v}(\mathrm{C}=\mathrm{C})$ frequency and band in the region $870-720^{\mathrm{cm}-1}$ may be due to $v(\mathrm{C}=\mathrm{H})$ stretch vibrations in benzene ring. The IR band appeared at $1040-950^{\mathrm{cm}-1}$ may be assigned to vc-0 in five membered ring. A IR band of medium intensity appearing at $3540^{\mathrm{cm}-1}$ may be assigned to $v\left(-\mathrm{NH}_{2}\right)$ stretching frequency in amide group.

Table-1: IR and PMR spectral data of the anil (ligand) Indeno-ethylidene-thiosemicarbazone: (IETS)

\begin{tabular}{|c|c|c|}
\hline & Spectral data & Assignments \\
\hline \multicolumn{3}{|c|}{ (A) IR (Nujol) $\mathrm{cm}^{-1}$} \\
\hline & 1. $3620(\mathrm{~s})$ & $v(\mathrm{O}-\mathrm{H}),($ phenolic $), v(\mathrm{~S}-\mathrm{H})$ \\
\hline & 2. $3050(\mathrm{~s})$ & v (C-H), str. (Aryl) \\
\hline & 3. $2965(\mathrm{~s})$ & $v(\mathrm{C}-\mathrm{H})$, str. $\left(-\mathrm{CH}_{3}\right)$ \\
\hline & 4. $1700(\mathrm{~s}), 1680(\mathrm{~s})$ & v $\mathrm{C}=\mathrm{O}$, str. (Five membered ring) \\
\hline & 5. $1640(\mathrm{~s}), 1460(\mathrm{~s})$ & v $\mathrm{C}=\mathrm{N}, \mathrm{str}$ \\
\hline & 6. $1610(\mathrm{~s}), 1510(\mathrm{~s}), 1450(\mathrm{~s})$ & v $\mathrm{C}=\mathrm{C}$, str, (Benzene ring) \\
\hline & 7. $1310-1240(\mathrm{~s})$ & v $\mathrm{C}=\mathrm{N}, \mathrm{str}$ \\
\hline & 8. $1040-950(\mathrm{~s})$ & v $\mathrm{C}-\mathrm{O}$, (Five membered ring) \\
\hline & 9. $870(\mathrm{~s}), 740(\mathrm{~s}), 720(\mathrm{~s})$ & $v(\mathrm{C}-\mathrm{H})$, (Benzene ring) \\
\hline & 10. $3540(\mathrm{~m})$ & $v(-\mathrm{NH} 2), \mathrm{Str}$ (amide) \\
\hline \multicolumn{3}{|c|}{ (B) $\operatorname{PMR}\left(\mathrm{CDCl}_{3}\right) \delta$} \\
\hline & 1. $2.75(\mathrm{~s})$ & $5 \mathrm{H},\left(\right.$ Aniline ring, $\mathrm{C}_{2}-\mathrm{H}$ to $\mathrm{C}_{6}-\mathrm{H}$ ) \\
\hline & 2. $\quad 7.40-7.60(\mathrm{~m})$ & $4 \mathrm{H}$, (Benzene ring, $\mathrm{C}_{4}-\mathrm{H}$ to $\mathrm{C}_{7}-\mathrm{H}$ ) \\
\hline & 3. $12.30(\mathrm{~m})$ & $1 \mathrm{H}, \mathrm{C}_{3}-\mathrm{OH}$ (enolic) \\
\hline
\end{tabular}


In PMR spectra of the ligand a sharp signal at $\delta, 2.75$ may be assigned to three protons of $\left(-\mathrm{CH}_{3}\right)$ group in The $-\mathrm{N}=\mathrm{C}-\mathrm{CH}_{3}$ PMR signal in the range of $\delta 7.40-7.60$ may be due to $4 \mathrm{H}$ (protons) of benzene ring $\mathrm{C}_{4}-\mathrm{H}$ to $\mathrm{C}_{7}-\mathrm{H}$. (aryl). The appearance of PMR signal of medium sharp intensity of $\delta 12.30$ may be due to $1 \mathrm{H}$ (enolic) in $\mathrm{C}_{3}-\mathrm{OH}$. This is supported by IR spectra of the ligand which was transparent in the region $3400-3200^{\mathrm{cm}-1}$. This suggests that the anil exists exclusively in the enol form.

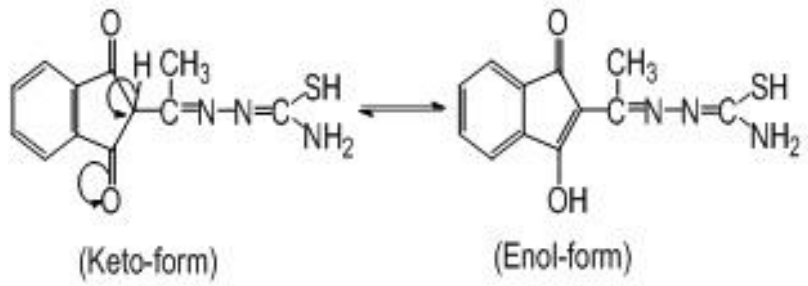

The mass spectral studies ${ }^{36,37}$ of the anils used in this work displays common mode of fragmentation. The mass-spectra of this anil (IETS) showed the molecular ion peak as a base peak at $\mathrm{m} / \mathrm{z} 261$.

\section{Metal derivatives:}

The metal derivatives of the ligand, IETS were prepared by refluxing reaction mixture of metal halides and ligand in methanol solution on water bath for 1-3 hours. The coloured solid products were obtained. The solid products were found insoluble in water, ether, alcohol and other common organic solvents . The metal complexes are thermally stable at higher temperature ( $\left.300^{\circ}\right)$. these characteristics suggest polymeric nature of the metal complexes.

\section{Structure of Metal derivatives}

The structure of the metal complexes has been elucidated by spectral studies, magnetic moment and molar conductivity measurements.

The colour physical state and magnetic moment data of the complexes have been presented in the table 2

Table 2: The physical state, colour and magnetic moment data of the metal - complexes of the ligand, Indeno ethylidene - thiosemicarbazone (IETS, $\left.\mathrm{L}_{2} \mathrm{H}_{2}\right)$

\begin{tabular}{|c|l|l|c|}
\hline S. No. & \multicolumn{1}{|c|}{ Complex } & Colour and Physical state & Magnetic moment $\mu$ eff. R.M. \\
\hline 1. & $\mathrm{Co}\left(\mathrm{L}_{2} \mathrm{H}\right) \mathrm{Cl}$ & Red brown, solid & 3.85 \\
\hline 2. & $\mathrm{Co}\left(\mathrm{L}_{2} \mathrm{H}\right)_{2}$ & Red brown, solid & $\ldots \ldots$ \\
\hline 3. & $\mathrm{Ni}\left(\mathrm{L}_{2} \mathrm{H}\right) \mathrm{Cl}$ & Redish brown, solid & 3.40 \\
\hline 4. & $\mathrm{Ni}\left(\mathrm{L}_{2} \mathrm{H}\right)_{2}$ & Redish brown, solid & $\ldots \ldots$ \\
\hline 5. & $\mathrm{Cu}\left(\mathrm{L}_{2} \mathrm{H}\right) \mathrm{Cl}$ & Yellowish brown, solid & $\ldots .78$ \\
\hline 6. & $\mathrm{Cu}\left(\mathrm{L}_{2} \mathrm{H}\right)_{2}$ & Orange- brown, solid & $\ldots \ldots$ \\
\hline 7. & $\mathrm{Zn}\left(\mathrm{L}_{2} \mathrm{H}\right) \mathrm{Cl}$ & Yellow - brown, solid & $\ldots \ldots$ \\
\hline 8. & $\mathrm{Zn}\left(\mathrm{L}_{2} \mathrm{H}\right)_{2}$ & Yellow - brown, solid & $\ldots \ldots$ \\
\hline 9. & $\mathrm{Cd}\left(\mathrm{L}_{2} \mathrm{H}\right) \mathrm{Cl}$ & Yellow - brown, solid & $\ldots \ldots$ \\
\hline 10. & $\mathrm{Cd}\left(\mathrm{L}_{2} \mathrm{H}\right)_{2}$ & Yellow - brown, solid & 5.75 \\
\hline 11. & $\mathrm{Fe}\left(\mathrm{L}_{2} \mathrm{H}\right) \mathrm{Cl}_{2} .2 \mathrm{CH}_{3} \mathrm{OH}$ & Yellow - brown, solid & $\ldots \ldots$ \\
\hline 12. & $\mathrm{Fe}\left(\mathrm{L}_{2} \mathrm{H}\right)_{2} \mathrm{Cl} .2 \mathrm{CH}_{3} \mathrm{OH}$ & Yellow - brown, solid & $\ldots \ldots$ \\
\hline 13. & $\mathrm{Fe}\left(\mathrm{L}_{2} \mathrm{H}\right)_{3}$ & Yellow - brown, solid & 3.70 \\
\hline 14. & $\mathrm{~V}\left(\mathrm{~L}_{2} \mathrm{H}\right) \mathrm{Cl}_{2} \cdot 2 \mathrm{CH}_{3} \mathrm{OH}$ & Yellow - brown, solid & $\ldots \ldots$ \\
\hline 15. & $\mathrm{~V}\left(\mathrm{~L}_{2} \mathrm{H}\right)_{2} \mathrm{Cl} \cdot \mathrm{CH}_{3} \mathrm{OH}$ & Yellow - brown, solid & $\ldots \ldots$ \\
\hline 16. & $\mathrm{~V}\left(\mathrm{~L}_{2} \mathrm{H}\right)_{3}$ & Yellow - brown, solid & 3.80 \\
\hline 17. & $\mathrm{Cr}\left(\mathrm{L}_{2} \mathrm{H}\right) \mathrm{Cl}_{2} \cdot 2 \mathrm{CH}_{3} \mathrm{OH}$ & Yellow - brown, solid & $\ldots \ldots$ \\
\hline 18. & $\mathrm{Cr}\left(\mathrm{L}_{2} \mathrm{H}\right)_{2} \mathrm{Cl}_{2} \mathrm{CH}_{3} \mathrm{OH}$ & Yellow - brown, solid & $\ldots \ldots$ \\
\hline 19. & $\mathrm{Cr}\left(\mathrm{L}_{2} \mathrm{H}\right)_{3}$ & Yellow - brown, solid & \\
\hline
\end{tabular}

Where, $\mathrm{L}_{2} \mathrm{H}=$ Ligand anion $\left(\mathrm{C}_{12} \mathrm{H}_{10} \mathrm{~N}_{3} \mathrm{O}_{2} \mathrm{~S}\right)^{-}$

\section{IR and PMR spectral studies}

The experimental IR spectral data of the metal derivatives have been presented in table 3

The IR spectra of metal derivative shows absence of $v(\mathrm{O}-\mathrm{H})$ (phenolic) in case of $\mathrm{Co}$ (II) and N(II) derivative which shows metal-ligand bonding through $(\mathrm{O}-\mathrm{H})$ (phenolic) group while in other metal complexes IRbands are observed in the range $3610-3600^{\mathrm{cm}-1}$ due to $v(\mathrm{O}-\mathrm{H})$ (phenolic). The presence of IR-band in the range $3060-3040^{\mathrm{cm}-1}$ may be due to $v(\mathrm{C}-\mathrm{H})$ (aryl) stretching vibrations. The sharp and intense IR band at 2960$2950^{\mathrm{cm}-1}$ may be assigned to $\mathrm{v}(\mathrm{C}-\mathrm{H})$ frequency of $-\mathrm{CH}_{3}$ group. The intense bands appearing in the region 1660- $1640^{\mathrm{cm}-1}$ may be assigned to $\mathrm{v} \mathrm{C}=0$ (carbonyl) frequency. The absorption of carbonyl group $(\mathrm{C}=\mathrm{O})$ at lower frequency than free $v(C=O)$ frequency at $1710-1700^{\mathrm{cm}-1}$ indicate participation of carbonyl group $(\mathrm{C}=\mathrm{O})$ to coordinate with metal ion in complexes.

The IR-spectra of the complexes shows IR absorption bands for various groups present in the structure of the complexes such as $v(\mathrm{C}=\mathrm{C})$ (benzene ring) band appears in the rnge $1640-1410^{\mathrm{cm}-1}$, the band in region 1630-1430 appear due to $v(\mathrm{C}=\mathrm{N})$ frequency, $v(\mathrm{C}-\mathrm{N})$ appears at $1340-1250^{\mathrm{cm}-1}$, v(C-O) appear at $1060-940^{\mathrm{cm}-1}, \mathrm{v}(\mathrm{M}-\mathrm{O})$ bands appear at $820-340^{\mathrm{cm}-1} v(\mathrm{M}-\mathrm{Cl})$ band appear at 280 $240^{\mathrm{cm}-1}$ and $v(\mathrm{M}-\mathrm{N})$ absorption bands are observed at $440-410^{\mathrm{cm}-1}$. 
The PMR spectrum of the metal complexes in quite similar to the PMR spectrum of the anil (IETS) with slight change in the position of PMR signals. The most of the PMR signal in metal complexes were observed at the expected positions as in ligand spectra but a broad PMR singal at $\delta 12: 30$ due $\mathrm{C}_{3}-\mathrm{OH}$ (Phenolic) was absent in $\mathrm{Co}$ (II) and NI (II) complexes due to its participation in metal-ligand bonding. This confirms complex formation.

\section{The magnetic moment measurements}

The magnetic moments of the metal derivatives were measured by Gouy method at room temperature $25^{\circ}$. The experimental magnetic moment values of the complexes have been presented in the table- 2 .

The observed magnetic moment values of the Co(III) complexes of the ligand (IETS) lie in the range 3.853.90B.M. the normally observed magnetic moments data for $\mathrm{Co}(\mathrm{II})\left(\mathrm{d}^{7}\right)$ spin free complexes lie in the range 4.30 5.20B.M. thus the measured magnetic moment values of Co(II) complexes of this anil indicate that the complexes are magnetically concentrated.

The magnetic moment values of $\mathrm{Ni}(\mathrm{II})$ complexes of the anil fall in the range $3.40-3.50 \mathrm{BM}$. this shows antiferromagnetic behaviors of $\mathrm{Ni}$ (II) complexes. The expected magnetic moment values of $\mathrm{Ni}$ (II) $\left(\mathrm{d}^{8}\right)$ spin free complexes have been observed in the range 2.903.40B.M. The measured magnetic moment values of $\mathrm{Cu}$ (II) magnetic moments for $\mathrm{Cu}$ (II) ( $\mathrm{d}^{9}$ ) spin free complexes fall in the range 1.75-1.80B.M. thus the observed magnetic moments of $\mathrm{Cu}$ (II) complexes of this anil are in quite agreement to their expected magnetic moment values. The $\mathrm{Zn}$ (II) and Cd (II) complexes do not show magnetic moment values in the applied magnetic field. This behaviour is in good agreement with expected magnetic behaviour of $\mathrm{Zn}$ (II) and $\mathrm{Cd}$ (II complexes the Fe (II), V (III) and Cr (III) complexes of this anil show their magnetic moments to be 585BM. 3.80BM. and 3.85BM. respectively. These values show the complexes to be paramagnetic and ferromagnetic is applied magnetic field.

\section{Molar conductivity Measurements}

The molar conductance of few of the 1:1 molar ratio complexes have been determined in their solutions in dimethyl sulphoxide (DMSO) solvent at room temperature The measured molar conductance values for some complexes of the anil are presented in the table- 4 . The observed molar conductance values of the complexes with this anil (IETS) have been found in the range 170 to $250 \mathrm{mhos} \mathrm{cm}^{2} \mathrm{~g} \mathrm{~mol}^{-1}$. These values show that complexes are feebly ionic in nature, though the complexes are insoluble in common organic solvents and water and hence the complexes are polymeric covalent compounds. But the possibility of their partial ionic character cannot be overlooked. This is also supported by their thermal stability and high M .P. ( above $\left.250^{\circ}\right)$. 
Table 3: The principal IR spectra data of 1:1 molar metal derivatives of the ligand, Indan - ethylidene thiosemicarbazone (IETS) and their assignments. (Abriviations, $\mathrm{s}=$ sharp, $\mathrm{m}=$ median,

$\mathrm{L}_{2}=$ ligand anion $\left(\mathrm{C}_{12} \mathrm{H}_{10} \mathrm{~N}_{3} \mathrm{O}_{2} \mathrm{~S}\right)^{-} \quad$ str= stretch. $)$

\begin{tabular}{|c|c|c|c|c|c|c|c|c|c|}
\hline $\begin{array}{l}\dot{0} \\
\dot{z}\end{array}$ & 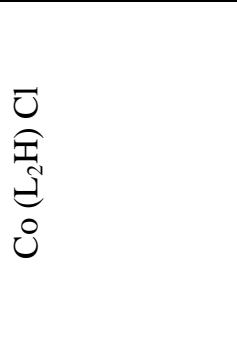 & 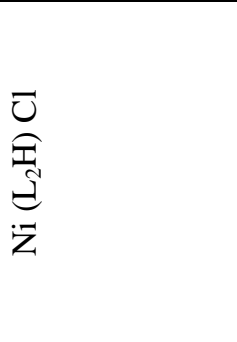 & 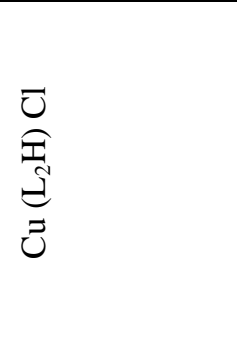 & 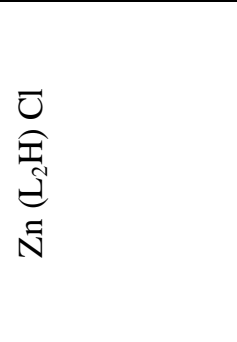 & 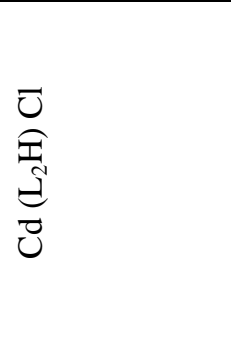 & 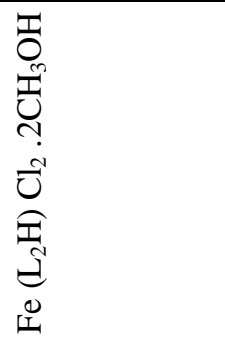 & 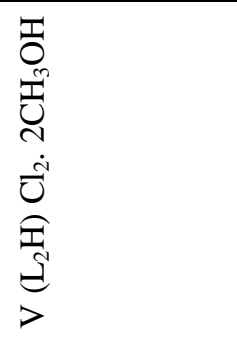 & 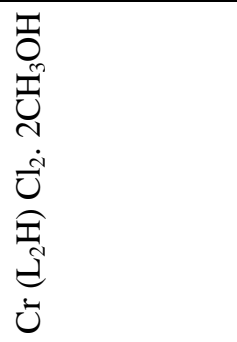 & Assignment \\
\hline 1 & ........ & $\ldots \ldots \ldots$ & 3600 & 3600 & 3600 & 3610 & 3610 & 3610 & $v(\mathrm{O}-\mathrm{H})($ Phenolic) \\
\hline 2 & $3060(\mathrm{~s})$ & $3050(\mathrm{~s})$ & $3040(\mathrm{~m})$ & $3045(\mathrm{~s})$ & $3040(\mathrm{~m})$ & $3050(\mathrm{~s})$ & $3060(\mathrm{~s})$ & $3040(\mathrm{~m})$ & $v(\mathrm{C}-\mathrm{H})($ Aryl $)$ \\
\hline 3 & $2950(\mathrm{~m})$ & $2950(\mathrm{~m})$ & $2960(\mathrm{~s})$ & $2960(\mathrm{~m})$ & $2940(\mathrm{~s})$ & $2950(\mathrm{~m})$ & $2940(\mathrm{~m})$ & $2960(\mathrm{~s})$ & $v(\mathrm{C}-\mathrm{H})\left(-\mathrm{CH}_{3}\right)$ \\
\hline 4 & $1650(\mathrm{~s})$ & $1650(\mathrm{~s})$ & $1640(\mathrm{~s})$ & $1650(\mathrm{~s})$ & $1660(\mathrm{~m})$ & $1650(\mathrm{~m})$ & $1640(\mathrm{~s})$ & $1630(\mathrm{~s})$ & $v(\mathrm{C}=\mathrm{O}), \mathrm{Str}$ \\
\hline 5 & $1610,1420(\mathrm{~s})$ & $1610,1430(\mathrm{~s})$ & $\begin{array}{c}1620(\mathrm{~s}), 1420 \\
\text { (s) }\end{array}$ & $\begin{array}{c}1630(\mathrm{~s}), 1440 \\
(\mathrm{~m})\end{array}$ & $\begin{array}{c}1620(\mathrm{~s}), 1420 \\
\text { (s) }\end{array}$ & $\begin{array}{c}1630(\mathrm{~s}), 1440 \\
(\mathrm{~m})\end{array}$ & $\begin{array}{c}1620(\mathrm{~s}), 1430 \\
(\mathrm{~s})\end{array}$ & $\begin{array}{c}1640(\mathrm{~s}), 1430 \\
\text { (s) }\end{array}$ & $v(\mathrm{C}=\mathrm{N}), \mathrm{str}$ \\
\hline 6 & $1530(\mathrm{~s}), 1420$ & $\begin{array}{c}1600(\mathrm{~s}), 1480 \\
\text { (s) }\end{array}$ & $\begin{array}{c}1590(\mathrm{~s}), 1440 \\
\text { (s) }\end{array}$ & $\begin{array}{c}1580(\mathrm{~s}), 1420 \\
(\mathrm{~s})\end{array}$ & $\begin{array}{c}1640(\mathrm{~s}), 1410 \\
\text { (s) }\end{array}$ & $\begin{array}{c}1580(\mathrm{~s}), 1420 \\
\text { (s) }\end{array}$ & $\begin{array}{c}1610(\mathrm{~s}), 1420 \\
(\mathrm{~s})\end{array}$ & 1590,1410 & $v(\mathrm{C}=\mathrm{C}),($ Benzene ring $)$ \\
\hline 7 & $\begin{array}{c}1360(\mathrm{~m}), 1210 \\
(\mathrm{~s})\end{array}$ & 1340,1230 & 1320,1230 & 1340,1250 & 1340,1260 & 1330,1220 & 1330,1240 & 1310,1220 & $v(\mathrm{C}-\mathrm{H}), \mathrm{str}$ \\
\hline 8 & $1050-940(\mathrm{~s})$ & $1060-930(\mathrm{~s})$ & $1050-930(\mathrm{~s})$ & $1030-940(\mathrm{~s})$ & $1040-960(\mathrm{~s})$ & $1040-940(\mathrm{~s})$ & $1020-920(\mathrm{~s})$ & $1050-940(\mathrm{~s})$ & \\
\hline 9 & $860-720(\mathrm{~s})$ & $870-730(\mathrm{~s})$ & $850-740(\mathrm{~s})$ & $870-720(\mathrm{~s})$ & $840-730(s)$ & $850-740(\mathrm{~s})$ & $840-730(\mathrm{~s})$ & $850-730(\mathrm{~s})$ & \\
\hline 10 & $350(\mathrm{~s}), 810(\mathrm{~s})$ & $340(\mathrm{~s}), 810(\mathrm{~s})$ & $360(\mathrm{~s}), 830(\mathrm{~s})$ & $320(\mathrm{~s}), 790(\mathrm{~s})$ & $330(\mathrm{~s}), 820(\mathrm{~s})$ & $340-810(\mathrm{~s})$ & $350(\mathrm{~s}), 820(\mathrm{~s})$ & $340(\mathrm{~s}), 810(\mathrm{~s})$ & \\
\hline 11 & $270(\mathrm{~s})$ & $240(\mathrm{~s})$ & $280(\mathrm{~s})$ & $260(\mathrm{~s})$ & $250(\mathrm{~s})$ & $260(\mathrm{~s})$ & $270(\mathrm{~s})$ & $280(\mathrm{~s})$ & \\
\hline 12 & $430(\mathrm{~s})$ & $430(\mathrm{~s})$ & $420(\mathrm{~s})$ & $410(\mathrm{~s})$ & $430(\mathrm{~s})$ & $430(\mathrm{~s})$ & $440(\mathrm{~s})$ & $420(\mathrm{~s})$ & \\
\hline
\end{tabular}


Table 4: Molar conductivity data of 1:1 molar ratio complexes of the ligand (IETS) measured at room temperature, $25^{0} \mathrm{C}$.

\begin{tabular}{|c|c|c|c|c|c|c|}
\hline $\begin{array}{l}\text { S. } \\
\text { No. }\end{array}$ & Complex & $\begin{array}{lr}\text { Conc. } & \text { Of } \\
\text { solution } & \text { in } \\
\text { DMSO } & \end{array}$ & $\begin{array}{l}\text { Observed } \\
\text { conductance } \\
\text { micro mhos }\end{array}$ & $\begin{array}{l}\text { Cell } \\
\text { constant }\end{array}$ & $\begin{array}{l}\text { Specific } \\
\text { conductance } \\
\text { mictomhos }\end{array}$ & $\begin{array}{l}\text { Molar } \\
\text { conductance } \\
\mathrm{cm}^{2} / \text { g. mol }\end{array}$ \\
\hline 1. & $\mathrm{Co}\left(\mathrm{L}_{2} \mathrm{H}\right) \mathrm{Cl}$ & $1 \times 10^{-3} \mathrm{M}$ & 1700 & 0.1 & 170.0 & 170.0 \\
\hline 2. & $\mathrm{Ni}\left(\mathrm{L}_{2} \mathrm{H}\right) \mathrm{Cl}$ & $1 \times 10^{-3} \mathrm{M}$ & 1740 & 0.1 & 174.0 & 174.0 \\
\hline 3. & $\mathrm{Cu}\left(\mathrm{L}_{2} \mathrm{H}\right) \mathrm{Cl}$ & $1 \times 10^{-3} \mathrm{M}$ & 1750 & 0.1 & 175.0 & 175.0 \\
\hline 4. & $\mathrm{Zn}\left(\mathrm{L}_{2} \mathrm{H}\right) \mathrm{Cl}$ & $1 \times 10^{-3} \mathrm{M}$ & 1800 & 0.1 & 180.0 & 180.0 \\
\hline 5. & $\mathrm{Cd}\left(\mathrm{L}_{2} \mathrm{H}\right) \mathrm{Cl}$ & $1 \times 10^{-3} \mathrm{M}$ & 1750 & 0.1 & 175.0 & 175.0 \\
\hline 6. & $\mathrm{Fe}\left(\mathrm{L}_{2} \mathrm{H}\right) \mathrm{Cl}_{2}$ & $1 \times 10^{-3} \mathrm{M}$ & 2300 & 0.1 & 230.0 & 230.0 \\
\hline 7. & $\mathrm{~V}\left(\mathrm{~L}_{2} \mathrm{H}\right) \mathrm{Cl}_{2}$ & $1 \times 10^{-3} \mathrm{M}$ & 2350 & 0.1 & 235.0 & 235.0 \\
\hline 8. & $\mathrm{Cr}\left(\mathrm{L}_{2} \mathrm{H}\right) \mathrm{Cl}_{2}$ & $1 \times 10^{-3} \mathrm{M}$ & 2450 & 0.1 & 245.0 & 245.0 \\
\hline
\end{tabular}

\section{Mass Spectral Studies}

The mass-spectra of these compounds show the presence of molecular peak, base peak and various fragmentation patterns.

The $\mathrm{M}^{+}-1$ ion peaks showed variable intensities. In the mass-spectra of the ligand molecular ion peak $\left(\mathrm{M}^{+}\right)$was observed at $\mathrm{m} / \mathrm{z} 261(100)$ and $\mathrm{M}^{+}-1$ peak was observed at $\mathrm{m} / \mathrm{z} 260$ (70) intensity.

The most probable structure for the $\mathrm{M}^{+}-1$ peak seems to be one derived through the loss of most acidic hydrogen to located at $\mathrm{C}_{2}$ of the indane-dione moety. The fragmentation process of the ligand starts with the elison of a ${ }^{\circ} \mathrm{CH}_{3}$ radical $(\mathrm{m} / \mathrm{z}, 15)$ from the molecular ion $\left(\mathrm{M}^{+}\right.$ $\mathrm{m} / \mathrm{z}$ 261). The resultant $\left(\mathrm{M}^{+}-\mathrm{CH}_{3}\right)$ ion $(\mathrm{m} / \mathrm{z}, 246)$ loss a $\mathrm{CN}(\mathrm{m} / \mathrm{z}, 26)$ radical to afford the ion $(\mathrm{m} / \mathrm{z} 220)$ and $\mathrm{m} / \mathrm{z}$ 246. This shows loss of methyl cyanide reported earlier from a Schiff's base.

The mass-spectra of Cobalt, Nickel and Copper derivatives of the ligands (IETS) in 1:1 molar ratio presented similar fragmentation pattern. The molecular ion peaks $\left(\mathrm{M}^{+}\right)$and variable intensities such as molecular ion peaks $\mathrm{m} / \mathrm{z} 354(100) \mathrm{m} / \mathrm{z}, 436(100)$ and $\mathrm{m} / \mathrm{z}$, 359(100) for Cobalt, Nickel and Copper respectively were observed. Similarly base ion peaks were observed at $\mathrm{m} / \mathrm{z}, 353, \mathrm{~m} / \mathrm{z}, 435$ and $\mathrm{m} / \mathrm{z}, 358$ respectively. The loss of methyl radical $\left(\mathrm{CH}_{3}\right)$ at $\mathrm{m} / \mathrm{z}, 15$ and methyl cynide, $\mathrm{m} / \mathrm{z}, 41$ were observed in the mass spectra of these complexes.

\section{Electronic spectral studies:}

The electronic spectra of cobalt (II), Nickel (II) and Copper (II) complexes with the ligand indeno-ethylidene thiosemicarbazone (IETS) in 1:1 molar ratio have been obtained and interpretated for their structures.

The Co (II) ion has the electronic configuration $\mathrm{d}^{7}$ and its ground state configuration in an octrahedral field may be $\mathrm{t}_{2} \mathrm{~g}^{5} \mathrm{~g}^{2}$ in weaker field or $\mathrm{t}_{2} \mathrm{~g}^{6} \mathrm{eg}^{1}$ in stronger fields. The electronic spectra of Co (II) (IETS) complexes showed three absorption bands in the region $1600-2200^{\mathrm{cm}-1}$ due to three spin-allowed transitions originated from the ground state $4 \mathrm{~T}_{1}(\mathrm{~F})$ to states $4 \mathrm{~T}_{2}\left(\mathrm{v}_{1}\right), 4 \mathrm{~A}_{2}\left(\mathrm{v}_{2}\right)$ and $4 \mathrm{~T}_{1}(\mathrm{P})\left(\mathrm{v}_{3}\right)$ as shown below.

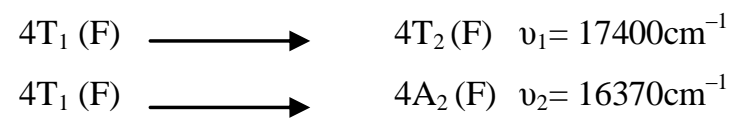

$4 \mathrm{~T}_{1}(\mathrm{~F})$

$$
4 \mathrm{~T}_{1}(\mathrm{~F}) \quad \mathrm{v}_{3}=19850 \mathrm{~cm}^{-1}
$$

The absorption band at $19850^{\mathrm{cm}-1}$ may be due to spinforbidden transition or due to low symmetry effect of the ligand. These absorption bands could be assigned to octahedral geometry of the complexes.

The Nickel (II) (IETS) complex spectra exhibites three absorption bands at $11000\left(v_{1}\right), 18540\left(v_{2}\right)$ and 30050 $\left(v_{3}\right)^{\mathrm{cm}-1}$. These absorption bands originate from $3 \mathrm{~A}_{2} \mathrm{~g}$ ground state transition to $3 \mathrm{~T}_{2} \mathrm{~g} 2 \mathrm{~T}_{1} \mathrm{~g}(\mathrm{~F})$ and $3 \mathrm{~T}_{1} \mathrm{~g}(\mathrm{P})$ states. These transitions could be shown as

$$
\begin{array}{lll}
3 \mathrm{~A}_{2 \mathrm{~g}} & \longrightarrow & 3 \mathrm{~T}_{2 \mathrm{~g}} \quad \mathrm{v}_{1}=11000 \mathrm{~cm}^{-1} \\
3 \mathrm{~A}_{2 \mathrm{~g}} \longrightarrow & 3 \mathrm{~T}_{1 \mathrm{~g}}(\mathrm{~F}) \mathrm{v}_{2}=18540 \mathrm{~cm}^{-1} \\
3 \mathrm{~A}_{2 \mathrm{~g}} \longrightarrow 3 \mathrm{~T}_{1 \mathrm{~g}}(\mathrm{P}) \mathrm{v}_{3}=30050 \mathrm{~cm}^{-1}
\end{array}
$$

The transmittance spectra of Copper (II) (IETS) complex shows at $13350^{\mathrm{cm}-1}$ which could be assigned to a distorted band octahedral structure proposed earlier ${ }^{34}$

An additional band was also observed at $23580^{\mathrm{cm}-1}$. This band has been assigned to metal-metal interactions by some investigators ${ }^{33,35}$. Thes observations are the characterstic features of the spectra of octahedral $\mathrm{Cu}$ (II) complexes. Thus $\mathrm{Cu}$ (II) (IETS) complexes may be assigned distorted octahedral or square coordination of Copper (II). The presence of two shoulders at $16670^{\mathrm{cm}-1}$ and $11000^{\mathrm{cm}-1}$ suggest distorted octahedral or square planar structure of $\mathrm{Cu}$ (II) complexes of the ligand.

The metal derivatives of the ligand indan-ethylidenethiosemicarbazone are coloured solid substances. They are insoluble in water and common organic solvents

They are infusible at higher temperature (above $250^{\circ}$ ). these characteristics suggest that the complexes may be polymeric in nature.

On the basis of physio-chemical properties of the metal complexes the structure of complexes have been suggested in which metal ions exhibit tetra and hexacoordination geometry depending upon the nature of metal ions and complexing agent the general structure of the metal complexes may be representated as follows: 
1. General structure of bi-valent metal complexes:

(i) 1:1 molar complexes:

(a)

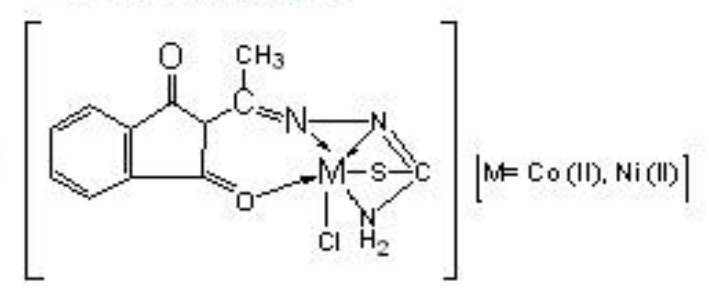

(10)

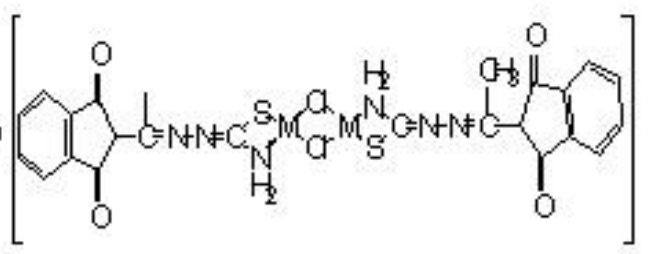

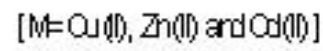

(ii) 1:2 mol ar complexes:

(a)

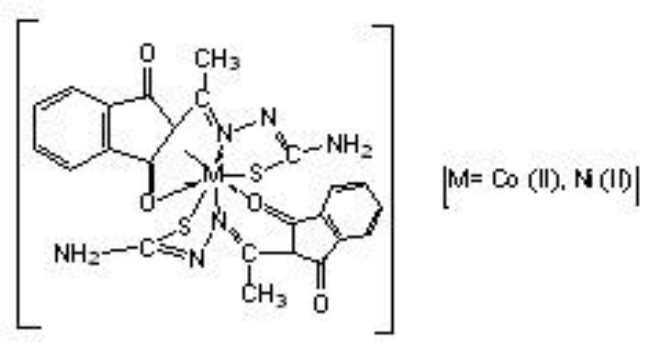

(b)<smiles>[M]C12CCCC(C1)SC(=NN=C(C)C1C(=O)c3ccccc3C1=O)N2</smiles>

2. General structures of trivalent metal complexes:

(i) 1:1 mol ar ratio complexes:

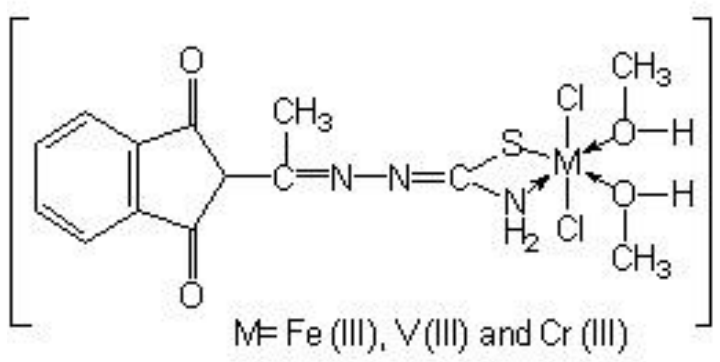

(ii) 1:2 molar ratio complexes:

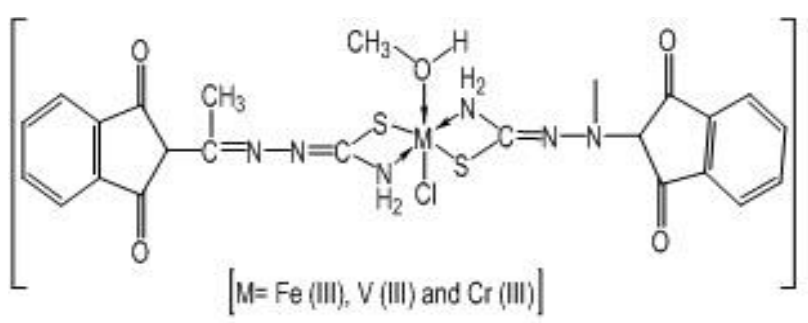

(iii) 1:3 molar ratio complexes:<smiles>CC(=NN=C(NC(C)(C)C)C(C)(C)C)C1C(=O)c2ccccc2C1=O</smiles>

Like coordinated water complexes the hexa coordination of $\mathrm{Fe}$ (III), V (III) and $\mathrm{Cr}$ (III) ions in 1:1 and 1:2 molar ratio complexes may be achieved by coordination of method molecules as donor species.

\section{SUMMARY}

The coordination chemistry has been recognized as an unique branch of chemistry. Transition metal ions have unique capacity of complex formation with variety of ligands. This study has originated wide applications in different branches of Science and Engineering. A large number of coordination compounds are of biological importance. The results of the present investigation have been described dealing with the synthesis and spectral studies of heterocyclic ligands with indan-1,3-dione moiety and their metal derivatives.

From the detailed survey of the literature on condensed heterocyclic ring systems. It is evident that indenoquinolines and indenopyrazoles show various physiological properties such as potent analgesics, antipyretics, anti-inflammatory agents etc. Indenoquinolines and indenopyrazoles consist indan -1 , 3-dione moiety which may be responsible for their biological activity. This suggests that indan-1, 3-dione derivatives may possible exhibit this property also with this fact is thoughts the present investigation has been carried out which includes synthesis of 2-substituted indan dione ketone and their schiff's bases (anils) by condensation of indan-1, 3-dione ketones with thiosemicarbazene. The synthesized Schiff's base IETS has been used to synthesize and characterize metal derivatives of transition metal ions.

The general approach towards the synthesis of these Schiff's bases (ligands) consists two step synthesis. In the first step of synthesis the starting materials 2substituted, Acetyl-indane-1, 3-dione has been synthesized by claisen-condensation of diethylphathalate with acetone and accetophenone respectively in presence of sodium methoxide in methanol. The second step involves the condensation 2-substituted indan-1, 3dione ketones with thiosemicarbazene in presence ethanol. The metal derivatives of the synthesized Schiff's bases (anils) have been prepared by using a hydrous metal chlorides of the following metal ions: $\mathrm{Co}(\mathrm{II})$, $\mathrm{Ni}(\mathrm{II}), \mathrm{Cu}(\mathrm{II}), \mathrm{Zn}(\mathrm{II}), \mathrm{Cd}(\mathrm{II}), \mathrm{Fe}(\mathrm{III}), \mathrm{V}(\mathrm{III})$ and $\mathrm{Cr}$ (III).

The formulation and structure of the IETS have been screened by their chemical analysis, IR, PMR and massspectral studies.

The metal complexes of the anils have been prepared by refluxing metal salt and ligands solution in methanol 
solvent in different molar ratios of metal to ligand on water bath for 1-3 hours. The complexes obtained are colored solid products. The solid coloured complexes have been found insoluble in water, alkalies and common organic solvents. The complexes are thermally stable and infusible at higher temperatures $\quad\left(\sim 300^{\circ} \mathrm{c}\right)$. These characteristics observed in the metal complexes indicate the complexes to be polymeric in nature.

A sharp intense band at $1700^{\mathrm{cm}-1}$ may be assigned to $v(\mathrm{C}=\mathrm{O})$ frequency in five membered ring. IR bands at $1640^{\mathrm{cm}-1}$ and $1460^{\mathrm{cm}-1}$ may be due to $v(\mathrm{C}=\mathrm{N})$ stretching vibrations.

The observed magnetic moment values of the Co(III) complexes of the ligand (IETS) lie in the range 3.853.90B.M. the normally observed magnetic moments data for $\mathrm{Co}(\mathrm{II})\left(\mathrm{d}^{7}\right)$ spin free complexes lie in the range 4.305.20B.M. thus the measured magnetic moment values of $\mathrm{Co}$ (II) complexes of this anil indicate that the complexes are magnetically concentrated.

\section{REFERENCES}

1. Singh, V. K. Ph. D. Thesis, K.U. Kurukshetra (Harayana) Dec. 1993.

2. Fox, H. H., J. Org. Chem. 1952, 17, 555.

3. Dhumwad SD, Gudasi K.B, Gudar TR., Ind. J. Chem., 1994, 33A, 320.

4. French, F.A. and Banz, E.J., J. Cancer Res. 1966, 36, 1638

5. Mishra, V. S., Verma, R. S. and Agarwal, S., J. Ind. Chem. Soc. $1975,52,981$.

6. Rai BK. Ind. Council of Chem. 2005, 22(2), 5.

7. Rai BK. and Baluni, A. Asian J. Chem. 2001, 13, 1589 1595

8. Rai BK. and Kumar, M., J. Ind. Council Chem. 2003, 20, 22.

9. Klayman, D. L. Scovill, J.P., Bartosevich, J. F., Bruch J. J. Med. Chem. 1983, 26, 35.

10. Philip, V. Suni, V. Kurup, M.R.P Netaji, M. Polyhedron, 2006, 25, 1931.

11. French, F. A. Blanz jr. E. J. J. Med. Chem. 1996, 9, 585.

12. Das, M., Living stone, S. E., Br. J. Cancer, 1978, 37,466

13. Dobak. A. S., Clayman, D.L., Dickson, L.T. Scovill, J.P. Tramont, E. C. Antimicrob, Agents Chemother, 1980, 18 27.

14. Usman, A. Razak, I. A., Chantrapromma, S., Fun. A. H. K., Acta cryst, C, 2002, 461

15. Clayman, D. L. Lin, A. J., Mc Call, J. W., J. Med. Chem. 1994, 34, 1422.

16. Shipman, G., C. Smith, H., Drach, J. C., Clayman, D. L., Antiviral Res. 1996, 6, 197.

17. El. Sawaf, A.K., West, D. X., El. Bahnasway, R. H. El. Said, F.A. Transition. Med. Chem. 1998, 23, 227.

18. Atonini, I., Claudi, P., Franchetti, M., Grifantini, S., Moore, A.E., j. Med. Chem. 1977, 20, 447.

19. Sonawane, P., Kumbhar, A., Padhye, S.B., Butcher, R.J., Transition Met. Chem. 1994,19, 277.

20. Thomas, J., Parmeswaran, G., Asian, J. Chem. 2002, 14, 1354.

21. Petrow, V. and Kahan, H.J., J. Chem. Soc. 1949, 2128.
The PMR spectrum of the metal complexes in quite similar to the PMR spectrum of the anil (IETS) with slight change in the position of PMR signals. The most of the PMR signal in metal complexes were observed at the expected positions as in ligand spectra but a broad PMR singal at $\delta 12: 30$ due $\mathrm{C}_{3}-\mathrm{OH}$ (Phenolic) was absent in $\mathrm{Co}$ (II) and NI (II) complexes due to its participation in metal-ligand bonding. This confirms complex formation.

The metal complexes are thermally stable at higher temperature $\left(-300^{\circ}\right)$. These characteristics suggest polymeric nature of the metal complexes.

The observed molar conductance values of the complexes with this anil (IETS) have been found in the range 170 to 250 mhos $\mathrm{cm}^{2} \mathrm{~g} \mathrm{~mol}{ }^{-1}$. These values show that complexes are feebly ionic in nature, though the complexes are insoluble in common organic solvents and water and hence the complexes are polymeric covalent compounds. But the possibility of their partial ionic character cannot be overlooked. This is also supported by their thermal stability and high M .P. $\left(-\right.$ above $\left.250^{\circ}\right)$.

22. Norman, H. and Cromwell, A., J. Org. Chem. 1961, 26, 3812-17.

23. Coombes, R. V. and Haulihan, W. J. J. Heterocyclic. Chem. $1971,8,855$.

24. Palta, N., Rao, B.V. Dubey, S. N. and Puri, D. M., Polyhedron, 1984, 3, 527

25. Mehrotra, R. C. and Puri, D. M., J. Less. Common metals 1961, 3, 253.

26. Mehrotra, R. C. and Puri, D. M., J. Ind. Chem. Soc. $\underline{39}$ (1962) 447, 499

27. Puri, D.M. Ph.D. thesis, university of Gorakhpur (1962).

28. Vogel,A.I. "Quantitative Inorganic analysis" Longman's Green \& Co. Ltd. $5^{\text {th }}$ Ed., John Wiley \& Sons Inc. New York (1989) P. 480.

29. Vogel, A. I., Jeffery,G.H., Bassett, J., Mendhoz, J. and Denny, R.c., "Quantitative Chemicsl Analysis Co. Ltd." $5^{\text {th }}$ Edn. John Wiley \& sons, Inc. New York, (1989) P. 457.

30. Vogel, A. I., Jeffery,G.H., Bassett, J., Mendhoz, J. and Denny, R.c., "Quantitative Chemicsl Analysis Co. Ltd." $5^{\text {th }}$ Edn. John Wiley \& sons, Inc. New York, (1989) P. 454.

31. Vogel, A. I., Jeffery,G.H., Bassett, J., Mendhoz, J. and Denny, R.c., "Quantitative Chemicsl Analysis Co. Ltd." $5^{\text {th }}$ Edn. John Wiley \& sons, Inc. New York, (1989) P. 462.

32. Vogel, A. I., Jeffery,G.H., Bassett, J., Mendhoz, J. and Denny, R.c., "Quantitative Chemicsl Analysis Co. Ltd." $5^{\text {th }}$ Edn. John Wiley \& sons, Inc. New York, (1989) P. 455.

33. Figgis, B. N. "Introduction to ligand field" wiley interscience, New York, 1976.

34. G. S. Sanyal, A. B. Modak, K. and Mubi, A. K., Ind. J. chem. 21A (1982) 1044.

35. Mc. Farlane, W and whrte, RFM, "Techniques of high Resolution Nuclear Magnetic Resonance spectroscopy" (Butterworths, London) 1972, 125.

36. Elias, D. J. \& Gillis, R. G. Aust. J. chem., 1966,19, 2511 , 29 (1969) 2249

37. Curran, D. J. \& Siggis, S. "The chemistry of carbon Nitrogen double bond" Interscience Publishers, Inc. New York, 1970, 172. 